\title{
Entomological and Ecological Aspects of Six Sylvatic Species of Triatomines (Hemiptera, Reduviidae) from the Collection of the National Biodiversity Institute of Costa Rica, Central America
}

\author{
Rodrigo Zeledón $/{ }^{+}$, Jesús A Ugalde*, Luis A Paniagua* \\ Escuela de Medicina Veterinaria, Universidad Nacional, Apartado Postal 86, Heredia, Costa Rica \\ *Instituto Nacional de Biodiversidad, Santo Domingo, Heredia, Costa Rica
}

\begin{abstract}
A total of 797 specimens of wild adult triatomines, belonging to six species from the entomological collections of the Costa Rican National Biodiversity Institute, was studied from the standpoint of their relative abundance, as reflected by light traps, distribution in the country, seasonal variations and climatic and altitudinal preferences.

Triatoma dimidiata was the most abundant species (32.9\% of the total specimens), with a very extensive distribution in different ecological zones, being more common between 100 to $400 \mathrm{~m}$ above sea level mainly at the end of the dry season. T. dispar was the third in frequency (21.5\%), with narrower distribution, more abundant between 600 to $800 \mathrm{~m}$ and scarce during the dry season. Panstrongylus geniculatus and $\mathrm{P}$. rufotuberculatus, second and fourth in frequency (22.1\% and $15.1 \%$, respectively), were widely distributed on both the Pacific and Caribbean basins, the former being more common between 80 to $270 \mathrm{~m}$ all year round and the latter below $800 \mathrm{~m}$ mainly during the first semester. Eratyrus cuspidatus which represented only $4.9 \%$ of the insects, was also present on both basins mainly below $200 \mathrm{~m}$ with a tendency to be scarce during certain months of the year, and was found in all types of ecological zones. Finally, Rhodnius pallescens, the least abundant species (3.6\%) was restricted to very humid areas below $20 \mathrm{~m}$, on the north side and Caribbean basin. With the exception of R. pallescens, males were more commonly found than females. Some epidemiological implications related to the six species are discussed.
\end{abstract}

Key words: triatomine - sylvatic species - Costa Rica

In their check list of the Reduviid bugs of Costa Rica, Coscarón and Jirón (1988), cited the following species of triatomines as reported for the country: Belminus costaricensis, B. rugulosus [this species, as indicated by Herrer et al. (1954), corresponds to B. costaricensis], Eratyrus cuspidatus [the report is attributed to Lent and Wygodzinsky (1947), but this publication does not mention the species, nor is it cited as present in Costa Rica by Lent and Wygodzinsky (1979), in their monograph], Panstrongylus geniculatus, P. rufotuberculatus, Rhodnius prolixus [this species enters Costa Rica with Nicaraguan immigrants but it was immediately eliminated as stated by Zeledón (1996)], R. pallescens, Triatoma dimidiata, T. dispar, T. nitida and T. ryckmani. All the above

\footnotetext{
${ }^{+}$Corresponding author. Fax: +506-225.3633. E-mail: rzeledon@sol.racsa.co.cr

Received 26 October 2000

Accepted 8 March 2001
}

records, with the exception of $T$. dimidiata, were based on the finding of one or a few specimens.

Since its creation in 1989, the Costa Rican National Biodiversity Institute (INBio) has aimed to carry out, among other goals, a national insect inventory. By taking advantage of the numerous specimens belonging to six of the above mentioned species, deposited in INBio's entomological collections, we report here some details of their relative abundance, their distribution, seasonal variations and their relationships with some climatic conditions.

\section{MATERIALS AND METHODS}

A total of 797 adult specimens of six wild triatomine species from INBio's collections were examined for identification and some ecological parameters of each of them were established by using INBio's data base. All specimens were collected from 1989 to 1998 , in or close to 30 biodiversity field stations located in the Costa Rican conservation areas (altitude range: 0 to $1,750 \mathrm{~m}$ ), representing all ecological zones of the country, which extends from 8 to $11^{\circ}$ North latitude and 
from 83 to $86^{\circ}$ West longitude. The specimens were collected by lights traps and the different collecting sites are indicated in Fig. 1.

Computer correlations were made with distribution, altitude, sex and relative abundance during the year and ecological regions by using Arc View, Version 3.1 software.

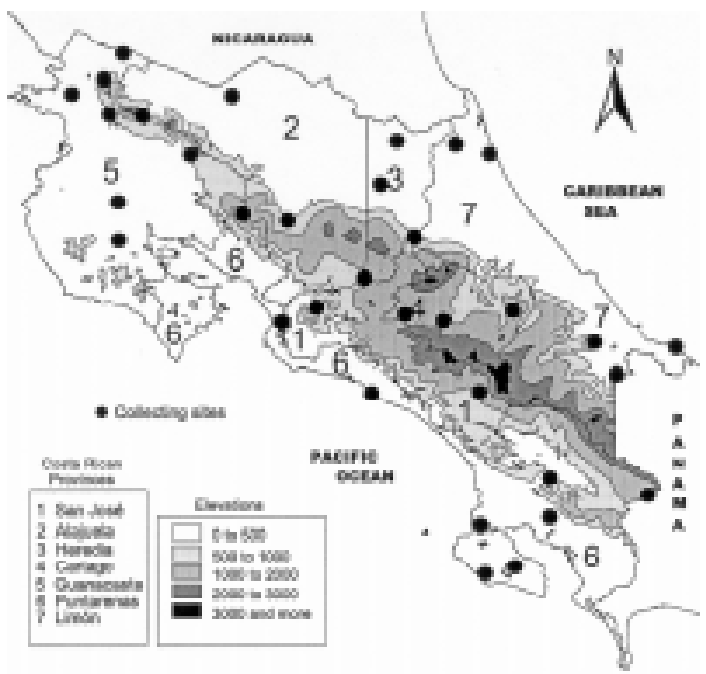

Fig. 1: map of Costa Rica showing the location of the 33 collecting sites where insects were captured.

\section{RESULTS}

The species found and their numbers, in parenthesis, were: T. dimidiata (262), T. dispar (171) $P$. geniculatus (176), P. rufotuberculatus (120), $R$. pallescens (29) (confirmed by Dr J Jurberg, Instituto Oswaldo Cruz, Rio de Janeiro, Brazil), and E. cuspidatus (39).

In Fig. 2 the distribution of the six species is observed. T. dimidiata, the most common species (32.9\% of the total specimens found), has a very extensive distribution in the country with the ex- ception of the south Pacific side and north central region where it was not found. T. dispar tends to be more common in the highlands, which run from northwest to southeast in the middle of the country, and towards the northern lowlands and the Caribbean basin, while it is absent from the $\mathrm{Pa}$ cific side and southeast mountains. This species represented $21.5 \%$ of all specimens, being third in frequency. P. geniculatus and $P$. rufotuberculatus are widely distributed in the lowlands of both the Pacific and the Caribbean basins but they are also represented on the northwest Pacific slopes and some central highlands. Together with $T$. dimidiata and $E$. cuspidatus, these two species reach higher concentrations in the Pacific side of the country. $P$. geniculatus and $P$. rufotuberculatus account for $22.1 \%$ (second in frequency) and $15.1 \%$ (fourth in frequency), respectively, of the specimens collected. R. pallescens was found only in the lowlands of the north side and in the Caribbean basin, whereas $E$. cuspidatus is present mainly along the Pacific basin, although it is also found on the Caribbean side. $R$. pallescens was the least frequent species encountered (3.6\% of the total) followed by E. cuspidatus (4.9\%).

The Province that provided most specimens was Guanacaste (49.2\% of the total for the country) with an evident predominance of $T$. dimidiata $(54.6 \%$ of the specimens from this Province) followed by T. dispar (26\%). In second place was the Province of Puntarenas with $26.9 \%$ of the total and a predominance of $P$. geniculatus $(50.9 \%$ of the specimens). In third place was the Province of Alajuela with $11 \%$ of the insects and a predominance of $T$. dispar (59.1\% of the specimens). The Province of Limon provided $7.7 \%$ of the total insects and the Provinces of Heredia, San Jose and Cartago, only $3.8 \%, 1 \%$ and $0.5 \%$ respectively (Table I).

As far as their distribution in relation to altitude is concerned, $T$. dimidiata occurs from sea level to $1,520 \mathrm{~m}$, with a higher concentration between 100

TABLE I

Number of specimens of triatomines distributed by provinces and by sex

\begin{tabular}{|c|c|c|c|c|c|c|c|c|c|c|c|c|c|c|c|}
\hline \multirow{3}{*}{ Species } & \multicolumn{14}{|c|}{ Provinces } & \multirow{3}{*}{ Totals } \\
\hline & \multicolumn{2}{|c|}{ Alajuela } & \multicolumn{2}{|c|}{ Cartago } & \multicolumn{2}{|c|}{ Guanacaste } & \multicolumn{2}{|c|}{ Heredia } & \multicolumn{2}{|c|}{ Limón } & \multicolumn{2}{|c|}{ Puntarenas } & \multicolumn{2}{|c|}{ San José } & \\
\hline & 우 & $0^{*}$ & q & $0^{*}$ & 우 & $0^{x}$ & q & $0^{x}$ & q & $0^{x}$ & $q$ & $0^{x}$ & ㅇ & $0^{*}$ & \\
\hline Triatoma dimidiata & - & - & - & 1 & 38 & 176 & 3 & 5 & 2 & 13 & 9 & 13 & 1 & 1 & 262 \\
\hline T. dispar & 28 & 24 & 2 & - & 47 & 55 & 1 & 3 & 3 & 5 & - & 1 & - & 2 & 171 \\
\hline Panstrongylus geniculatus & 1 & 6 & - & 1 & 5 & 20 & - & 13 & 1 & 17 & 22 & 87 & 1 & 2 & 176 \\
\hline P. rufotuberculatus & 3 & 7 & - & - & 11 & 29 & - & 4 & 3 & 5 & 17 & 41 & - & - & 120 \\
\hline Rhodnius pallescens & 13 & 5 & - & - & - & - & - & - & 7 & 4 & - & - & - & - & 29 \\
\hline Eratyrus cuspidatus & 1 & - & - & - & 1 & 10 & - & 1 & 1 & - & 3 & 21 & - & 1 & 39 \\
\hline Totals +9 and $0^{-\top} o^{*}$ & 46 & 42 & 2 & 2 & 102 & 290 & 4 & 26 & 17 & 44 & 51 & 163 & 2 & 6 & 797 \\
\hline Totals by province & \multicolumn{2}{|c|}{88} & \multicolumn{2}{|c|}{4} & \multicolumn{2}{|c|}{392} & \multicolumn{2}{|c|}{30} & \multicolumn{2}{|c|}{61} & \multicolumn{2}{|c|}{214} & \multicolumn{2}{|c|}{8} & 797 \\
\hline
\end{tabular}



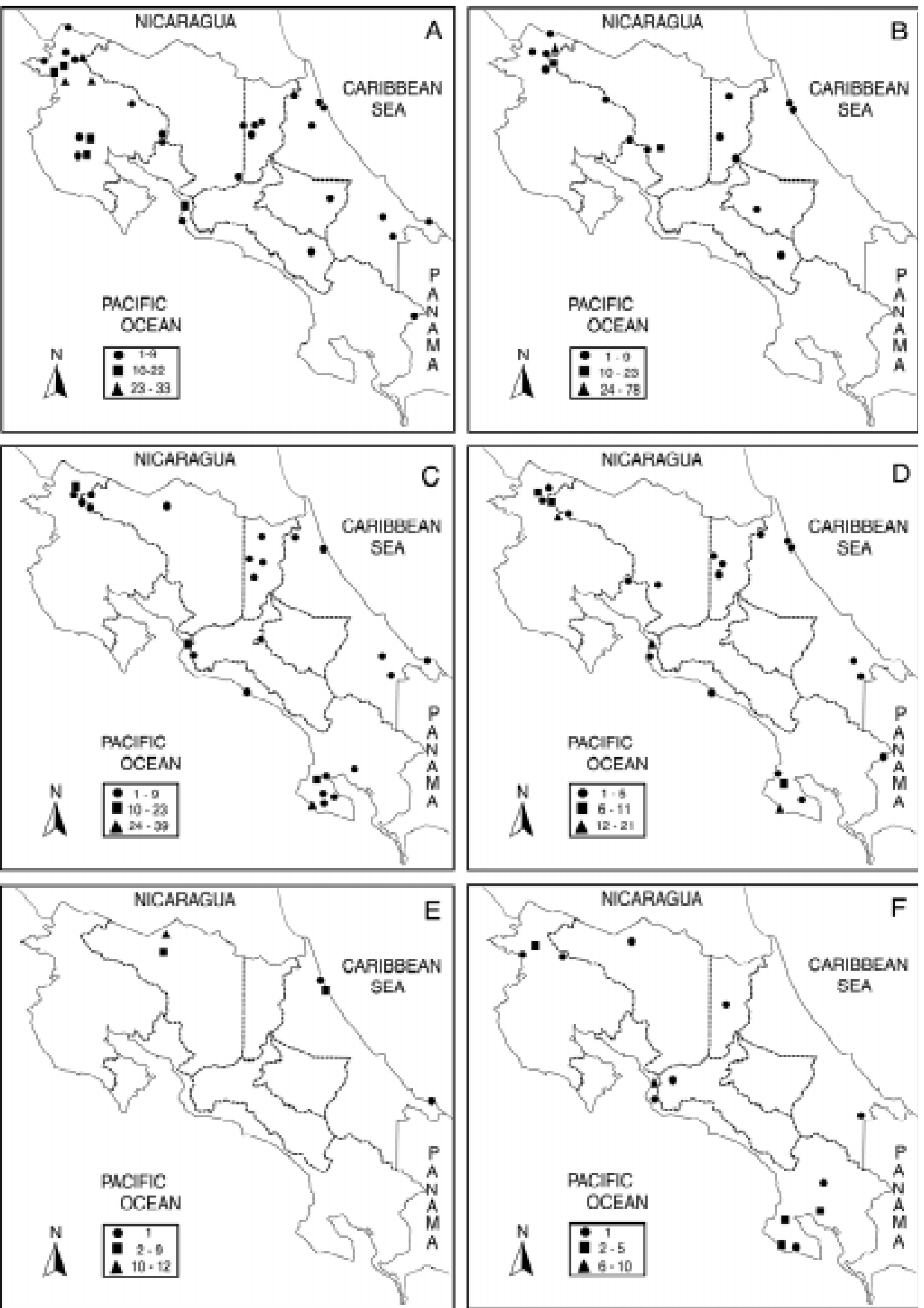

Fig. 2: maps of Costa Rica showing the distribution of each of the six sylvatic species of triatomines found and their relative concentrations. A: Tritoma dimidiata; B: T. dispar; C: Panstrongylus geniculatus; D: P. rufotuberculatus; E: Rhodnius pallescens; F: Eratyrus cuspidatus 
to $400 \mathrm{~m}$ ( $66.4 \%$ of the specimens) and with $92.3 \%$ of the insects below $800 \mathrm{~m}$. T. dispar is also distributed between sea level and $1,520 \mathrm{~m}$, being more abundant between 600 and $800 \mathrm{~m}(61.4 \%)$. P. geniculatus has a rather narrow range in this respect, from sea level to $700 \mathrm{~m}$, with a strong tendency to be more frequent between 80 and $270 \mathrm{~m}(80.1 \%)$. P. rufotuberculatus can be found from sea level to $1,450 \mathrm{~m}$, but seems to be more common at levels below $800 \mathrm{~m}(74.1 \%)$ and especially below $200 \mathrm{~m}$ (52.5\% of the specimens). $R$. pallescens is a species of the lowlands, not higher than $20 \mathrm{~m}$, and E. cuspidatus also has a tendency to inhabit rather low elevations, from sea level to $300 \mathrm{~m}$
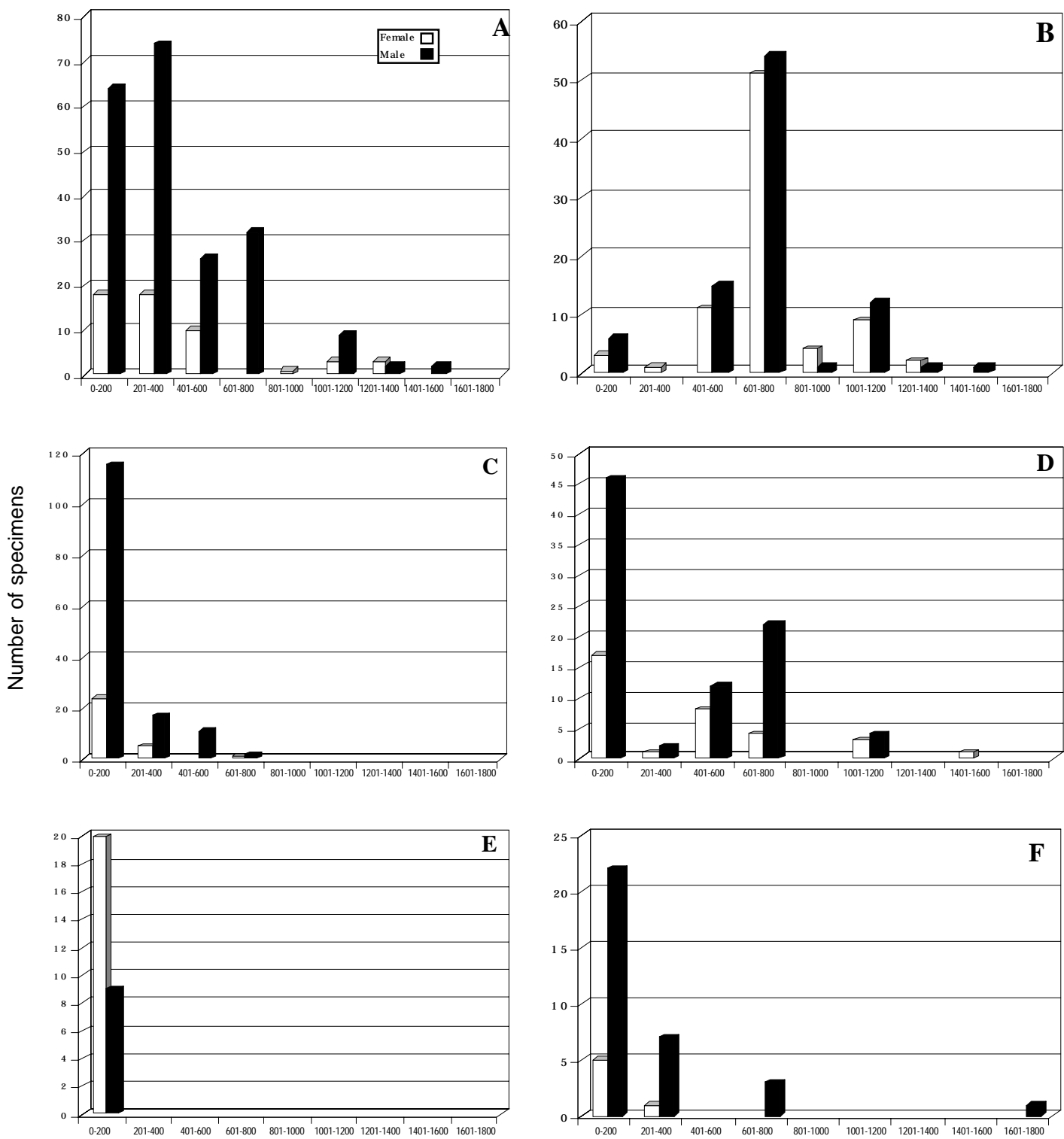

Altitude (m)

Fig. 3: number of specimens of the six sylvatic species of triatomines obtained in relation to altitude. A: Tritoma dimidiata; B: T. dispar; C: Panstrongylus geniculatus; D: P. rufotuberculatus; E: Rhodnius pallescens; F: Eratyrus cuspidatus

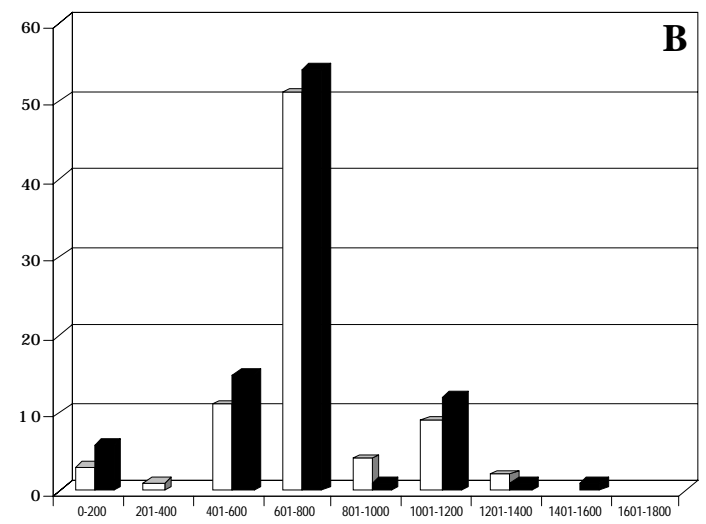

(69.2\% were obtained between 0 to $200 \mathrm{~m}$ ), and only rarely is found at higher elevations (Fig. 3).

With the exception of $R$. pallescens, in all cases, males were captured more frequently than females. The ratios of males to females were: 3.94 for $T$. dimidiata, 1.11 for $T$. dispar, 4.87 for $P$. geniculatus, 2.53 for $P$. rufotuberculatus, 0.45 for $R$. pallescens and 5.50 for E. cuspidatus.

In relation to time of year when the specimens were encountered, $T$. dimidiata was found all year round with peaks from March to May (end of the dry season). T. dispar had a marked peak in May but was present in lower numbers during most of 
the rest of the year, particularly during some of the dry months (November to March). P. geniculatus was found during the entire year with a peak at the end of the dry season (March and April). $P$. rufotuberculatus tended to be more common during the first six months of the year (dry season and beginning of the rainy season). $R$. pallescens and E. cuspidatus, the least abundant of the six species, tended to be even more scarce during certain months of the year, with a few exceptions such as February in both cases. For the former, females were usually more common, whereas for the latter, sometimes only males were captured (Fig. 4).

The distribution and frequency of the six spe-
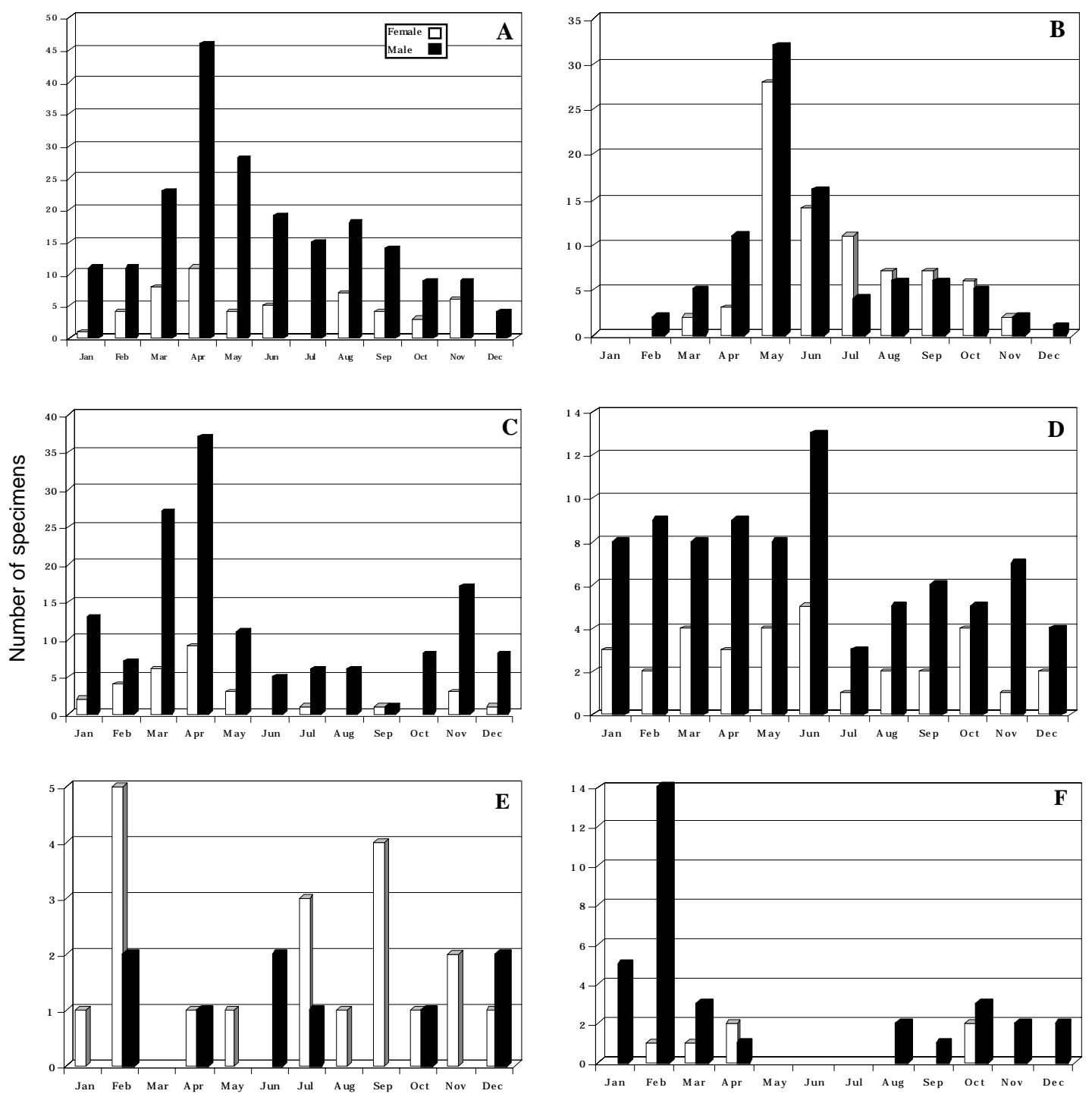

Months

cies in some of Holdridge's life zones (Holdridge 1987) are presented in Table II. Only T. dimidiata and $E$. cuspidatus can be found in most types of environments, including the Dry Tropical Forest, exhibiting a wide ecological valence. However, $T$. dimidiata populations concentrate mainly in $\mathrm{Hu}-$ mid and Very Humid Premountane Forest. All the other species are also associated mainly with humid and very humid environments.

\section{DISCUSSION}

The wild and domestic conditions of $T$. dimidiata in Costa Rica have been known for several years, representing the only important vector
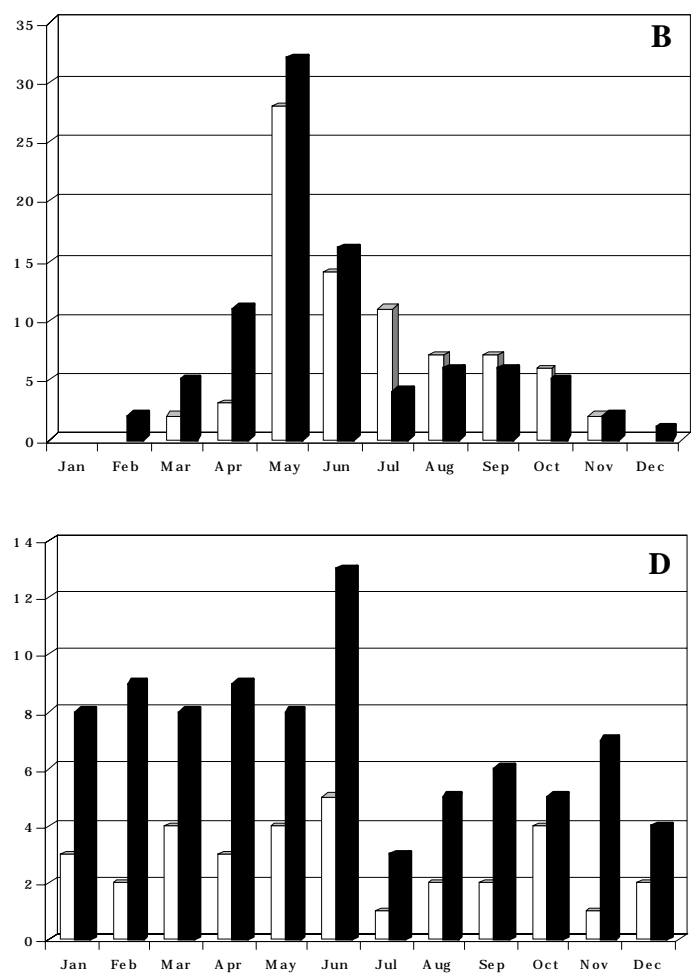

Fig. 4: number of specimens of the six sylvatic species of triatomines captured at different times of the year. A: Triatoma dimidiata; B: T. dispar; C: Panstrongylus geniculatus; D: P. rufotuberculatus; E: Rhodnius pallescens; F: Eratyrus cuspidatus 
of Chagas disease in the country (Zeledón 1981). The data here confirm how well this species is represented throughout the country in a variety of climates, and its permanent potential adaptation to artificial ecotopes when it is attracted by lights. The fact that the species is constantly invading human dwellings in many areas of the country, including new settlements far from or close to main towns, hinders the control of the species, which should be addressed by educational measures, leading to environmental management. This proximity of $T$. dimidiata to the most populated areas of the Central Plateau of the country, where some of the main cities are located, is not reflected in our data because no collecting sites were located in these points where urbanization has replaced the forest (Fig. 1). T. dimidiata is found in Latin America from Mexico to Perú and has been reported from sea level to 2,700 m (Jurberg et al. 1996).

The presence of $T$. dispar in the country was known from two previous reports. In the first one (Usinger 1944), it is referred to as T. venosa, and only in the key is it mentioned as present in Costa Rica; when the author presents the species description in the same publication, he attributed it to
Ecuador and Panama. By looking at Usinger's picture of the species, Lent recognizes that it was not T. venosa, and described it a few years later as $T$. dispar based on two female specimens from Ecuador and Panama (Lent 1950). In the second report, a male representing this species was found near Ciudad Quesada, Province of Alajuela, inside a house (Vargas \& Montero-Gei 1971). The species has also been found in Panama and in Northeast Ecuador, always at altitudes below $300 \mathrm{~m}$ (Jurberg et al. 1996). In our data it was the third most common sylvatic species, being absent in the drier areas of the Pacific side. On the other hand, it was more commonly found at higher altitudes than has been reported. It has not been found thriving in human dwellings.

$P$. geniculatus was the second most abundant species in our records and together with $P$. rufotuberculatus, the fourth in abundance, has a preference for humid climates even though the latter has a wider altitudinal range and is more easily found all year round. P. geniculatus is commonly associated with armadillos in their burrows and also with rodents and marsupials, and is strongly attracted by artificial lights; some times adults are

TABLE II

Distribution and frequency of sylvatic triatominae species according to Holdridge's life zone system (Holdridge 1967)

\begin{tabular}{|c|c|c|c|c|c|c|}
\hline \multirow[t]{2}{*}{ Life zones } & \multicolumn{6}{|c|}{ Species } \\
\hline & T. dim. & T. dis. & P. gen. & P. ruf. & R. pal. & E. cus. \\
\hline Dry Tropical Forest & 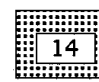 & & & & & 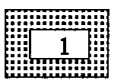 \\
\hline Humid Tropical Forest ${ }^{a}$ & & & & & 19 & 144 \\
\hline Very Humid Tropical Forest & \begin{tabular}{l}
$\because 5$ \\
$\because \because \because 9$ \\
\hdashline
\end{tabular} & $\because \frac{9}{9}$ & $\because \frac{91}{99}$ & $\therefore 44$ & $\begin{array}{l}\because 10 \\
\because \because \\
\because \because\end{array}$ & $\begin{array}{ll}\because & 13 \\
\because \because \\
\because\end{array}$ \\
\hline VHTF Transition to Premontane & $\because \frac{2}{\vdots}$ & 107 & & & & \\
\hline Humid Premontane Forest ${ }^{b}$ & 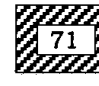 & & & & & $\begin{array}{l}2 \\
2 \\
7 Z Z\end{array}$ \\
\hline Very Humid Premontane Forest ${ }^{c}$ & 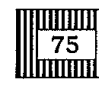 & IIIIIIII & ||س|| & $\mid$\begin{tabular}{c|c|c|}
32 \\
32
\end{tabular} & & IIIIII \\
\hline VHPF Transition to Lowland Forest & 堾 13 & & 全44 & 22兰 & & 11 要 \\
\hline Premontane Rain Forest & & & & $\because \frac{8}{8+3}$ & & $\Leftrightarrow$ \\
\hline
\end{tabular}

$a$ : include transitions to Premontane and to Dry Forest; $b$ : include transsition to Lowland Forest; $c$ : include transitions to Rain Forest, to Lowland Forest and to Lower Montane Forest; VHTF: Very Humid Tropical Forest; VHPF: Very Humid Premontane Forest; T. dim.: Triatoma dimidiata; T. dis.: T. dispar; P. gen.: Panstrongylus geniculatus; P. rufo.: P. rufotuberculatus; R. pal.: Rhodinius pallescens; E. cus.: Eratyrus cuspidatus 
found in houses but they usually do not thrive in them (Zeledón 1983). Naiff et al. (1998) reported finding adults in houses in Manaus, Brazil, with no signs of colonization. Males were more common during the dry season and their numbers were twice that of females. In a small riverine community in the Brazilian Amazon region, it was recently reported that adults of this species attack humans in their houses, and both adults and nymphs were found in peridomestic pigsties; the species was also found in palm trees in the surroundings (Valente et al. 1998). The species occurs from Argentina to Nicaragua but probably extends throughout all Middle America since it was recently reported from Mexico (Tay et al. 1992). It has been found at altitudes close to 1,700 $\mathrm{m}$ above sea level (Curto de Casas et al. 1996) but, according to our data, it seems to prefer lowlands.

P. rufotuberculatus has been found associated with wild mammals (kinkajous, bats and opossums) and adult specimens have been observed occasionally in human dwellings in Ecuador, Peru and Bolivia. More recently, in the latter country, four nymphs and one adult were found colonizing a house located in a forest environment; also, in Bolivia it has been found at altitudes that range between 1,500 to 2,600 m (Noireau et al. 1994). The species occurs from Mexico to Bolivia (Zarate $\&$ Zarate 1985) and more recently it was found for the first time in Argentina (Salomón et al. 1999).

$R$. pallescens is very dependent on high humidity and for this reason it is only found in very humid climates (Zeledón \& Rabinovich 1981). In certain areas of Panamá, it has been found colonizing human dwellings and serves as an important vector of Chagas disease (Pipkin 1968). It has also been found in palm trees, which serve as natural ecotopes for the species (Whitlaw \& Chaniotis 1978). In Costa Rica it is completely wild and only a few adults have been occasionally found inside houses in the Provinces of Alajuela and Limón (Marín \&Vargas 1986). It also exists wild in Belize and in Colombia below $300 \mathrm{~m}$ altitude (Galindez et al. 1996). In the latter country, it has been found in palm trees, it is attracted to lights and more recently a domiciliary cycle of the species has been demonstrated in the northern part of the country, where it transmits Chagas disease (Moreno \& Jaramillo 1996).

E. cuspidatus, which is here confirmed for the first time in Costa Rica, has a rather wide distribution in the country. It prefers the lowlands even though occasionally it can be found at high altitudes, and does not seem to be very exacting in relation to humidity. It has been reported from Mexico to northern Peru, including Ecuador, Colombia and Venezuela, and in Central America in
Guatemala and Panama; in Colombia it can be found under peridomiciliary conditions (Moreno \& Jaramillo 1996). It has been found up to 1,000 $m$ above sea level (Galvão et al. 1998).

\section{ACKNOWLEDGEMENTS}

To Dr Paul Hanson (School of Biology, University of Costa Rica), for his revision of the manuscript and to Dr José Jurberg (Oswaldo Cruz Institute, Rio de Janeiro, Brazil), for the confirmation of Rhodnius pallescens.

\section{REFERENCES}

Coscarón M del C, Jirón LF 1988. Updated checklist of assasin bug species (Hemiptera: Reduviidae) of Costa Rica. Brenesia 29: 107-113.

Curto de Casas SI, Carcavallo RU, Galíndez-Girón I, Jurberg J, Mena-Segura CA 1996. Geographical distribution and alti-latitudinal dispersion of species of Panstrongylus (Hemiptera, Reduviidae, Triatominae, Triatomini). Entomol Vect 3: 43-58.

Galíndez I, Curto de Casas SI, Carcavallo RU, Jurberg J, Mena Segura CA 1996. Geographical distribution and alti-latitudinal dispersion of the tribe Rhodniini (Hemiptera, Reduviidae, Triatominae). Entomol Vect 3: 3-20.

Galvão C, Jurberg J, Carcavallo RU, Mena-Segura CA,Galíndez-Girón I, Curto de Casas SI 1998. Distribuição geográfica e dispersão alti-latitudinal de alguns gêneros e espécies da tribo Triatomini Jeannel, 1919 (Hemiptera, Reduviidae, Tritominae). Mem Inst Oswaldo Cruz 93: 33-37.

Herrer A, Lent H, Wygodzinsky P 1954. Contribución al conocimiento del género Belminus Stal, 1859 (Triatominae, Reduviidae, Hemiptera). An Inst Med Reg Tucumán 4: 85-105.

Holdridge LR 1987. Ecología Basada en Zonas de Vida, Instituto Interamericano de Cooperación para la Agricultura, Costa Rica, 216 pp.

Jurberg J, Galvão C, Galíndez-Girón I, Carcavallo RU, Mena-Segura CA, Curto de Casas SI 1996. Distribución geográfica y dispersión altitudinal de las especies del género Triatoma Laporte, 1832 de Norte América, América Central y el Caribe. Entomol Vect 3: 87-120.

Lent H 1950. Nova espécie de “Triatoma” Laporte, 1833 (Hemiptera, Reduviidae). Rev Brasil Biol 10: 437440.

Lent H, Wygodzinsky P 1947. Sobre algunas especies de "Zelurus" Hahn (Reduviidae, Hemiptera). Rev Brasil Biol 7: 28-55.

Lent H, Wygodzinsky P 1979. Revision of the Triatominae (Hemiptera, Reduviidae), and their significance as vectors of Chagas' disease. Bull Am Mus Nat Hist 163: 123-520.

Marín RE, Vargas M 1986 Rhodnius pallescens (Hemiptera: Reduviidae) in Costa Rica. J Med Entomol 23: 333.

Moreno J, Jaramillo O 1996. Estudios epidemiológicaos sobre la enfermedad de Chagas en los Departamentos de Antioquia, Sucre, Tolima, Colombia. In CJ Schofield, JP Dujardin, J Jurberg (eds), Proc Intl Workshop on Population Genetics and Control of 
Triatominae, Santo Domingo de los Colorados, Ecuador, 24-28 Sept. 1995, INDRE, Mexico City, p. 27.

Naiff MdeF, Naiff RD, Barrett TV 1998. Vetores selváticos de doença de Chagas na área urbana de Manaus (AM): atividade de vôo nas estações secas e chuvosas. Rev Soc Brasil Med Trop 31: 103-105.

Noireau F, Bosseno MF, Vargas F, Brenière SF 1994. Apparent trend to domesticity observed in Pantrongylus rufotuberculatus Champion, 1899 (Hemiptera: Reduviidae) in Bolivia. Res Rev Parasitol 54: 263-264.

Pipkin AC 1968. Domiciliary reduviid bugs and the epidemiology of Chagas' disease in Panama (Hemiptera: Reduviidae: Triatominae). J Med Entomol 5: 107-124.

Salomón OD, Ripoll CM, Rivetti E, Carcavallo RU 1999. Presence of Panstrongylus rufotuberculatus (Champion, 1899) (Hemiptera: Reduviidae: Triatominae) in Argentina Mem Inst Oswaldo Cruz, 94: 285-288.

Tay J, Schenone H, Sánchez JT, Robert L 1992. Estado actual de los conocimientos sobre la enfermedad de Chagas en la República Mexicana. Bol Chile Parasitol 47: 43-53.

Usinger RL 1944 The Triatominae of North and Central America and the West Indies and their Public Health Significance, US Publ Hlth Bull no. 288, 83 pp.
Valente VC, Valente SAS, Noireau F, Carrasco HJ, Miles MA 1998. Chagas disease in the Amazon basin: association of Panstrongylus geniculatus (Hemiptera: Reduviidae) with domestic pigs. J Med Entomol 35: 99-103.

Vargas M, Montero-Gei F 1971. Triatoma dispar Lent, 1950 in Costa Rica. J Med Entomol 8: 454-455.

Whitlaw JT, Chaniotis BN 1978. Palm trees and Chagas' disease in Panama. Am J Trop Med Hyg 27: 873-881.

Zárate LG, Zárate RJ 1985. A checklist of the Triatominae (Hemiptera, Reduviidae) of Mexico. Intl $J$ Entomol 27: 102-127.

Zeledón R 1981. El Triatoma dimidiata (Latreille, 1811) y su relación con la enfermedad de Chagas, Editorial Universidad Estatal a Distancia, San José, 146 pp.

Zeledón R 1983. Vectores de la enfermedad de Chagas y sus características ecofisiológicas. Interciencia 8: 384-395.

Zeledón R 1996. Enfermedad de Chagas en Centroamérica. In CJ Schofield, J P Dujardin, J Jurberg, (eds) Proc Intl Workshop on Population Genetics and Control of Triatominae, Santo Domingo de los Colorados, Ecuador, 24-28 Sept. 1995, INDRE, Mexico City, p. 40.

Zeledón R, Rabinovich JE 1981. Chagas disease: an ecological appraisal with special emphasis on it insect vectors. Ann Rev Entomol 26: 101-133. 